\begin{tabular}{lll}
\hline VOLUME 9 & No. 1, 22 Desember 2019 & Halaman 1-85
\end{tabular}

\title{
Kinerja Usahatani Kelapa Sawit Lahan Gambut di Desa Dayun Kabupaten Siak
}

\author{
Performance of Coconut Palm Oil Farming \\ in Dayun Village, Siak District
}

\author{
*Muhammad Naufal \\ Magister Manajemen Agribisnis, Fakultas Pertanian, Universitas Gadjah Mada \\ Lestari Rahayu Waluyati dan Dwidjono Hadi Darwanto \\ Fakultas Pertanian, Universitas Gadjah Mada
}

Submitted: 21-09-2018; Revised:12-02- 2019; Accepted: 12-02-2019

\begin{abstract}
Palm oil farming land has expanded so that peatland use is sought to increase plantation productivity. However, peatland use for oil palm needs to be managed specifically because peat is a marginal land that vulnerable to environmental damage. This study aims to: 1) determine the factors that influence the production of palm oil farming. 2) determine how much the contribution of palm oil income to total household income of palm oil farmer. 3) determine the poverty level of peatland small farmers. The farmers' samples in this study were taken purposively for as many as 55 respondents in Dayun Village, Siak Regency. The sampling was done purposively with the consideration that the farmers interviewed were those who had "Productive Plants" of palm oil on peatlands. Multiple regression analysis with Ordinary Least Square (OLS) approach was used to analyze the factors influencing the production of peatland palm oil and to know the contribution of palm oil revenues to total household incomeproportions. In determining the poverty level, the analysis was conducted by using an approach based on household consumption expenditure and total household income. The minimum consumption requirement set by Central Statistics Bureau (BPS) as the poverty line (GK) was used as a comparison of the two approaches. The results showed that the variables influencing peatland oil palm production were land area, labor usage, dolomite fertilizers usage, $\mathrm{KCl}$ fertilizer usage, urea fertilizers usage, and farmer education level. Half of the total respondents have income from palm oil farming that contributes more than $50 \%$ of their total household incomes. For the level of poverty of farmers in Dayun Village, it had been found that more than $50 \%$ of peatland farmers (small farmers) in Dayun Village were in non-poor category.
\end{abstract}

Keywords: Factors of Production; Income Contribution; Palm Oil; Peatland; Poverty Level

\footnotetext{
ABSTRAK

Lahan usahatani kelapa sawit telah meluas hingga pemanfaatan lahan gambut diusahakan dapat meningkatkan produktivitas perkebunan. Namun penggunaan lahan gambut untuk kelapa sawit perlu dikelola secara khusus karena gambut merupakan lahan marjinal yang rentan akan rusaknya lingkungan. Penelitian ini bertujuan untuk: 1) menentukan faktor-faktor yang mempengaruhi produksi

*Corresponding author: naufalmontella@gmail.ugm.ac.id.

Copyright (C) 2019 THE AUTHOR(S). This article is distributed under a Creative Commons Attribution-Share Alike 4.0 International license. Jurnal Teknosains is published by the Graduate School of Universitas Gadjah Mada.
} 
usahatani kelapa sawit. 2) menentukan seberapa besar kontribusi pendapatan kelapa sawit terhadap total pendapatan rumah tangga petani sawit. 3) menentukan tingkat kemiskinan petani lahan gambut (petani kecil). Sampel petani dalam penelitian ini diambil secara purposive sebanyak 55 responden di Desa Dayun Kabupaten Siak. Pengambilan sampel dilakukan dengan pertimbangan bahwa petani responden adalah petani yang memiliki lahan "Tanaman Produktif" dari kelapa sawit di lahan gambut. Analisis regresi berganda dengan pendekatan Ordinary Least Square (OLS) digunakan untuk menganalisis faktor-faktor yang mempengaruhi produksi lahan gambut dan untuk mengetahui kontribusi pendapatan kelapa sawit terhadap total proporsi pendapatan rumah tangga yang digunakan. Dalam menentukan tingkat kemiskinan, analisis dilakukan dengan menggunakan pendekatan berdasarkan pengeluaran konsumsi rumah tangga dan total pendapatan rumah tangga. Kebutuhan konsumsi minimum telah ditetapkan oleh BPS sebagai garis kemiskinan (GK) digunakan sebagai perbandingan dari dua pendekatan. Hasil penelitian menunjukkan bahwa variabel yang mempengaruhi produksi lahan gambut adalah luas lahan, penggunaan tenaga kerja, penggunaan pupuk dolomit, penggunaan pupuk KCL, penggunaan pupuk urea, dan tingkat pendidikan petani. Setengah dari total responden memiliki pendapatan dari pertanian kelapa sawit yang menyumbang lebih dari $50 \%$ terhadap total pendapatan rumah tangga mereka. Untuk tingkat kemiskinan petani di Desa Dayun telah ditemukan bahwa lebih dari $50 \%$ petani lahan gambut (petani kecil) di Desa Dayun berada dalam kategori tidak miskin.

Kata kunci: Faktor Produksi; Kelapa Sawit; Kontribusi Pendapatan; Lahan Gambut; Tingkat Kemiskinan.

\section{PENGANTAR}

Kelapa sawit merupakan komoditas yang dapat dijadikan sumber energi alternatif yang dapat diperbaharui dan memiliki prospek yang cerah dimasa depan sebagai energi alternatif (energi biodiesel) yang dapat menggantikan minyak bumi yang semakin hari berkurang dan berpeluang akan habis. Kelapa sawit juga memiliki prospek yang cerah dari perkembangan pasar terhadap minyak yang merupakan salah satu sumber penyumbang devisa negara dari sektor non migas, sehingga pemerintah dan masyarakat terdorong untuk mengembangkan kebun kelapa sawit di Indonesia, baik perkebunan besar yang dikelolah pemerintah, swasta, maupun Perkebunan Inti Rakyat (PIR) (Sunarko 2009).

Di Indonesia pilihan terhadap lahan gambut sebagai lahan pertanian berawal dari keberhasilan masyarakat lokal dalam pemanfaatannya untuk pertanian baik tanaman pangan maupun perkebunan. Kelapa sawit memiliki kebutuhan tenaga kerja lebih rendah daripada tanaman alternatif (terutama karet), sehingga petani yang mengadopsi mampu mengelola lahan yang lebih luas. Biaya tenaga kerja yang dihemat melalui peralihan dari karet ke kelapa sawit juga digunakan untuk meningkatkan pendapatan lainnya di luar pertanian. Sebagian besar pengadopsi kelapa sawit lebih memilih memperluas ukuran lahan pertanian mereka daripada meningkatkan keuntungan yang lebih tinggi per hektar dkk., 2017)

Lahan gambut di Indonesia merupakan sumber daya lahan yang semakin penting untuk penghidupan masyarakat dan untuk pembangunan ekonomi, tetapi lahan gambut berubah menjadi sumber karbon ketika hutan gambut dibersihkan dan dikeringkan. Oleh karena itu, diperlukan strategi untuk pengelolaan lahan gambut berkelanjutan dan untuk mengurangi emisi gas rumah kaca (Agus dkk., 2012).

Keunggulan dari penggunaan lahan gambut sebagai media usahatani kelapa sawit, diantaranya adalah topografi landai, sehingga penggunaan lahan lebih mudah dibandingkan dengan lahan yang berbukit. Lahan gambut juga berpotensi menghasilkan produktivitas yang tinggi dengan teknik budidaya yang tepat. Pasalnya, lahan gambut mengandung bahan organik dari pelapukan organisme dan tumbuh-tumbuhan. Kelemahan gambut diantaranya $p H$ bersifat asam, miskin akan hara mikro, drainase yang buruk, kering tidak balik (irreversible drying), dan kesuburan yang relatif rendah. Selain itu, risiko terserang hama dan penyakit juga sering terjadi di lahan ini (Sunarko, 2009). 
Produksi kelapa sawit dipengaruhi oleh beberapa faktor. Faktor-faktor tersebut diantaranya faktor teknis dan sosial. Faktor teknis antara lain adalah luas lahan yang digunakan, penggunaan tenaga kerja, penggunaan pupuk (jenis dan kuantitasnya), penggunaan pestisida (jenis dan jumlah penggunaanya), dan lain-lain. Untuk faktor sosial antara lain seperti umur petani dan tingkat pendidikan petani. Alfayanti \& Efendi (2013) melakukan penelitian untuk menentukan faktor-faktor yang mempengaruhi produksi perkebunan kelapa sawit rakyat di Kabupaten Mukomuko Provinsi Bengkulu. Data dianalisis menggunakan model fungsi produksi Cobb-Douglas yang diolah dengan teknik analisis OLS (Ordinary Least Square). Temuan menunjukkan bahwa faktor yang mempengaruhi produksi kelapa sawit adalah umur dari tanaman dan tenaga kerja yang dicurahkan.

Hasil penelitian tentang financial assessment pada usahatani kelapa sawit lahan gambut yang dilakukan oleh Noormahayu dkk., (2009) di Selangor Malaysia, menunjukkan bahwa input kimia lebih penting daripada biaya tenaga kerja dalam menentukan tingkat output keuangan. Fungsi produksi Cobb-Douglas digunakan untuk memodelkan output keuangan dari kelapa sawit dalam hal biaya input agrokimia dan tenaga kerja.

Produksi TBS (tandan buah segar) kelapa sawit yang merupakan hasil dari usahatani kelapa sawit yang dijalankan oleh petani dapat mempengaruhi pendapatan rumah tangga petani. Semakin besar produksi TBS kelapa sawit yang dihasilkan oleh petani maka semakin besar pendapatan usahatani kelapa sawitnya. Pendapatan petani dari hasil usahatani kelapa sawit kemudian berkontribusi terhadap pendapatan total rumah tangga. Pendapatan total keluarga tani berasal dari usahatani dan luar usahatani. Pendapatan yang diperoleh merupakan pendapatan seluruh anggota rumah tangga tani (termasuk istri dan anak). Dalam menjalankan usahatani ada beberapa hal yang perlu diperhatikan yaitu biaya, penerimaan dan pendapatan usahatani (Gupito dkk., 2014).
Hasil dari penelitian yang dilakukan oleh Euler dkk., (2017), menunjukkan bahwa usahatani kelapa sawit dapat berkontribusi pada peningkatan kesejahteraan. Mengadopsi kelapa sawit dapat meningkatkan standar kehidupan rumah tangga dan gizi, yang artinya dampak pada pengeluaran makanan dan nonmakanan, serta konsumsi kalori dan kualitas makanan, semuanya positif dan signifikan. Kelapa sawit di Kabupaten Siak merupakan komoditas unggulan yang memberikan pendapatan masyarakat lebih baik dan terjamin dibandingkan komoditas pertanian lain seperti karet, kopi dan juga tanaman padi. Oleh karena itu, setiap tahun mengalami alih fungsi lahan pertanian menjadi kelapa sawit, khususnya di kalangan petani. Peningkatan produksi dan produktivitas sawit merupakan keharusan karena merupakan landasan dan prasyarat bagi proses industrialisasi sawit.

Berdasarkan penjelasan di atas, maka penelitian ini berusaha menjawab beberapa permasalahan diantaranya adalah faktor penentu yang mempengaruhi produksi kelapa sawit, mengidentifikasi kontribusi usahatani kelapa sawit terhadap pendapatan rumah tangga petani, dan tingkat kemiskinan petani di lahan gambut.

\section{Metode \\ Lokasi Penelitian}

Daerah penelitian ditentukan secara sengaja atau purposive sampling dengan mengambil lokasi di Desa Dayun, Kecamatan Dayun, Kabupaten Siak Provinsi Riau. Pemilihan lokasi dilakukan secara purposive dengan mempertimbangkan belum adanya penelitian mengenai usahatani sawit di lahan gambut di Desa Dayun Kabupaten Siak. Pertimbangan lain adalah homogenitas keadaan alam, kondisi usahatani dan karakteristik petani.

Sampel petani adalah petani yang berada di wilayah Desa Dayun yang melakukan usahatani kelapa sawit di lahan gambut. Sampel petani dalam penelitian ini diambil secara purposive sebanyak 55 responden. Pada teknik ini pengambilan subjek didasarkan tujuan tertentu bukan didasarkan atas strata 
dan keacakan. Pengambilan sampel secara purposive dilakukan dengan pertimbangan: 1) petani adalah petani yang mempunyai lahan TM (Tanaman Menghasilkan) kelapa sawit di lahan gambut. 2) petani bersedia untuk memberikan data yang berhubungan dengan produksi usahatani kelapa sawit.

\section{Metode Analisis}

Pengujian hipotesis faktor-faktor yang berpengaruh terhadap produksi usahatani kelapa sawit adalah dengan fungsi produksi Cobb-Douglas dengan metode OLS. Model persamaan yang digunakan dalam penelitian adalah sebagai berikut :

$\operatorname{Ln} Y=\operatorname{In} \alpha+\beta 1 \ln X 1+\beta 2 \ln X 2+\beta 3 \ln X 3$ $+\beta 4 \ln X 4+\beta 5 \ln X 5+\beta 6 \ln X 6+\beta 7 \ln X 7+\beta 8$ $\ln X 8+\beta 9 \ln X 9+\beta 10 \ln X 10+\beta 11 \ln X 11+u$

Di mana $Y$ adalah produksi TBS kelapa sawit TM (ton/th), $\alpha$ adalah intersep $\beta \mathrm{i}$ adalah koefisien regresi, $\mathrm{u}$ adalah kesalahan pengganggu dan $\mathrm{X} 1, \mathrm{X} 2, \mathrm{X} 3, \mathrm{X} 4, \mathrm{X} 5, \mathrm{X} 6, \mathrm{X} 7, \mathrm{X} 8$, $X 9, X 10$ secara berurutan adalah luas lahan TM (Ha), tenaga kerja $(\mathrm{HOK} / \mathrm{th})$, jumlah pupuk NPK (kg/th), jumlah pupuk dolomit ( $\mathrm{kg} / \mathrm{th}$ ), jumlah pupuk SP36 (kg/th), jumlah pupuk $\mathrm{KCl}$ $(\mathrm{kg} / \mathrm{th})$, jumlah pupuk urea $(\mathrm{kg} / \mathrm{th})$, jumlah pestisida $(1 /$ th), pendidikan petani (th), dan umur petani (th).

Analisis kemudian dilanjutkan dengan menghitung pendapatan usahatani sawit dan pendapatan total rumah tangga petani dengan menggunakan rumus-rumus sebagai berikut:

$$
\mathrm{Y} 1=(\text { Py.y })-(\text { Px.x }+ \text { TFC })
$$

Y1 merupakan pendapatan usahatani kelapa sawit lahan gambut, Py adalah harga output, y adalah jumlah output, Px adalah harga input, $x$ adalah jumlah input TFC adalah total biaya tetap

$$
\mathrm{Y}=\mathrm{Y} 1+\mathrm{Y} 2
$$

Keterangan :

Y : Total pendapatan rumah tangga

Y1 : Pendapatan rumah tangga dari usahatani kelapa sawit lahan gambut

Y2 : Pendapatanlainnya di luar usahatani kelapa sawit lahan gambut
Kemudian dilanjutkan dengan menghitung besaran kontribusi pendapatan usahatani kelapa sawit lahan gambut terhadap pendapatan total rumah tangga dan pengujian proporsi dengan uji Z. Persamaan yang digunakan adalah sebagai berikut:

$K=\frac{\text { Pendapatan Usahatani Sawit }}{\text { Pendapatan Total Rumah Tangga }} \times 100 \%$

Uji proporsi (satu arah):

$\mathrm{H}_{0}$ : Lebih dari $50 \%$ Petani responden yang pendapatan usahatani sawitnya berkontribusi lebih dari $50 \%$ terhadap pendapatan rumah tangganya $(\mu>0,5)$

$\mathrm{H}_{1}$ : Minimal 50\% Petani responden yang pendapatan usahatani sawitnya berkontribusi kurang dari $50 \%$ terhadap pendapatan rumah tangganya $(\mu \leq 0,5)$

Jika nilai $\mathrm{Z}$ hitung $\leq-\mathrm{Z}_{05}$ tabel maka $\mathrm{H} 0$ ditolak. Hal ini berarti tidak lebih dari 50\% petani responden yang pendapatan usahatani sawitnya berkontribusi lebih dari 50\% terhadap pendapatan rumah tangganya.

Jika nilai $\mathrm{Z}$ hitung $>-\mathrm{Z}_{, 05}$ tabel maka H0 diterima. Hal ini berarti lebih dari 50\% petani responden yang pendapatan usahatani sawitnya berkontribusi lebih dari 50\% terhadap pendapatan rumah tangganya.

Z hitung $=\frac{\mathrm{P}-\mathrm{P}_{o}}{\sqrt{\left(\mathrm{P}_{\mathrm{o}}\left(1-\mathrm{P}_{\mathrm{o}}\right)\right] / \mathrm{n}}}$

$\mathrm{p} \quad$ : Persentase yang didapat dari analisis (K)

$\mathrm{p}_{0} \quad$ : Persentase yang diduga

$\mathrm{n} \quad$ : Jumlah responden

Analisis kemudian dilanjutkan dengan menghitung tingkat kemiskinan rumah tangga petani kelapa sawit lahan gambut. Persamaan yang digunakan adalah sebagai berikut:

$$
\begin{aligned}
\mathrm{R}-\mathrm{KM} & =\frac{\text { Konsumsi Rumahtangga Petani }}{\mathrm{GK}} \\
& =\frac{\text { Pendapatan Total Rumahtangga Petani }}{\mathrm{GK}}
\end{aligned}
$$


Apabila nilai R-KM yang diperoleh kurang atau sama dengan satu, berarti penduduk tersebut dikategorikan sebagai miskin. Kemudian dilakukan uji proporsi dengan uji $Z$ untukjumlah petani yang berkategori miskin dan tidak miskin.

Uji proporsi:

$\mathrm{H}_{0} \quad$ : Jumlah petani tidak miskin lebih dari $50 \%(\mu>0,5)$

$\mathrm{H}_{1} \quad$ : Jumlah petani tidak miskin tidak lebih dari $50 \%(\mu \leq 0,5)$

Jika nilai $\mathrm{Z}$ hitung $\leq-\mathrm{Z}_{05}$ tabel maka $\mathrm{H}_{0}$ ditolak. Hal ini berarti jumlah petani miskin $50 \%$ atau lebih. Jika nilai $\mathrm{Z}$ hitung $>-\mathrm{Z}_{, 05}$ tabel maka $\mathrm{H}_{0}$ diterima. Hal ini berarti jumlah petani tidak miskin lebih dari $50 \%$.

$$
\begin{aligned}
\text { Z hitung } & =\frac{p-p_{o}}{\sqrt{P_{q}} / n} \\
\mathrm{p} & : \begin{array}{l}
\text { Persentase yang didapat dari } \\
\text { analisis }(\mathrm{K})
\end{array} \\
\mathrm{p}_{0} & : \text { Persentase yang diduga } \\
\mathrm{q} & \left.: \text { (1- } \mathrm{p}_{0}\right) \\
\mathrm{n} & : \text { Jumlah responden }
\end{aligned}
$$

\section{HASIL DAN PEMBAHASAN Faktor Produksi}

Penggunaan faktor produksi (input) dapat menggambarkan kemampuan seorang petani dalam menjalankan usaha perkebunan kelapa sawit. Adapun faktor produksi usahatani perkebunan kelapa sawit yang digunakan oleh petani kelapa sawit di Desa Dayun Kecamatan Dayun Kabupaten Siak yaitu faktor teknis dan faktor sosial. Faktor teknis diantaranya adalah luas lahan, tenaga kerja, pupuk NPK, pupuk dolomit, pupuk Sp36, Pupuk KCl, pupuk urea, dan pestisida. Faktor sosial yang digunakan adalah tingkat pendidikan petani dan umur petani.

Faktor luas lahan sebagai input merupakan variabel yang utama, sedangkan untuk input produksi pupuk, yang paling banyak diaplikasikan oleh petani adalah pupuk dolomit. Biaya penggunaaan variabel input produksi yang dikeluarkan oleh petani kelapa sawit lahan gambut di Desa Dayun Kecamatan
Dayun Kabupaten Siak meliputi tenaga kerja (TK) perawatan (penyiangan, prunning, pemupukan, dan pestisida), TK panen, biaya pupuk NPK, pupuk dolomit, pupuk Sp36, pupuk $\mathrm{KCl}$, pupuk urea, dan biaya pestisida dapat ditinjau pada tabel 1. berikut.

Tabel 1

Penggunaan Faktor Produksi Kelapa Sawit Setiap Petani di Desa Dayun

\begin{tabular}{ll}
\hline \multicolumn{1}{c}{ Variabel } & \multicolumn{1}{c}{$\begin{array}{c}\text { Rerata Biaya /Ha/ } \\
\text { Tahun (Rp) }\end{array}$} \\
\hline Upah TK Panen & 1.954 .020 \\
Upah TK Perawatan & 861.610 \\
Total Biaya TK & 2.815 .630 \\
Biaya Pupuk NPK & 652.789 \\
Biaya Pupuk Dolomit & 495.419 \\
Biaya Pupuk Sp3 & 172.371 \\
Biaya Pupuk KCl & 461.803 \\
Biaya Pupuk Urea & 416.212 \\
Biaya Pestisida & 374.995 \\
Total Biaya Produksi & 5.381 .947 \\
\hline
\end{tabular}

Sumber: Analisis Data Primer, 2018

Variabel dependen yang digunakan adalah produksi kelapa sawit dalam setahun, sedangkan variabel independen yang digunakan adalah yaitu faktor-faktor yang diduga mempengaruhi produksi. Faktor-faktor produksi seperti jumlah tenaga kerja, pupuk, dan pestisida jumlah penggunaannya dalam setahun. Untuk data pupuk yang digunakan adalah data yang berdasarkan penggunaan pupuk setahun sebelumnya karena pada tanaman perkebunan pengaruh pupuk dapat dirasakan setelah setahun penggunaannya. Hasil regresi linier berganda dapat ditinjau pada Tabel 2. berikut.

Tabel 2

Hasil Analisis Regresi Linier Berganda

\begin{tabular}{lllr}
\hline \multicolumn{1}{c}{ Variabel } & Koefisien & T hitung & Sig \\
\hline (Constant) & $-0,142$ & $-0,090^{\text {ns }}$ & 0,929 \\
Luas Lahan & 0,580 & $4,002^{\text {*k* }}$ & 0,000 \\
Tenaga Kerja & 0,392 & $1,751^{*}$ & 0,087 \\
Pupuk NPK & 0,001 & $0,020^{\text {ns }}$ & 0,984 \\
Pupuk Dolomit & 0,110 & $1,798^{*}$ & 0,079
\end{tabular}


Lanjutan Tabel 2.

\begin{tabular}{lllr}
\hline \multicolumn{1}{c}{ Variabel } & Koefisien & T hitung & Sig \\
\hline Pupuk Sp36 & 0,070 & $1,235^{\text {ns }}$ & 0,223 \\
Pupuk KCl & 0,095 & $1,958^{*}$ & 0,057 \\
Pupuk Urea & 0,085 & $2,692^{*}$ & 0,010 \\
Pestisida & $-0,052$ & $-0,744^{\text {ns }}$ & 0,461 \\
Pendidikan Petani & 0,221 & $1,764^{*}$ & 0,085 \\
Umur Petani & 0,238 & $1,190^{\text {ns }}$ & 0,240 \\
R-Square & & & 0,879 \\
Adjusted R Square & & & 0,852 \\
F & & 32,029 & 0,000 \\
\hline
\end{tabular}

Sumber: Analisis data primer, 2018

Keterangan:

*** = Signifikansi pada tingkat kepercayaan (99\%) t tabel $=2,69$

* = Signifikansi pada tingkat kepercayaan (95\%) t tabel $=2,01$

= Signifikansi pada tingkat kepercayaan $(90 \%) \mathrm{t}$ tabel $=1,68$

ns $=$ Tidak signifikan

Pada tabel 2. nilai R-square 0,879, menunjukkan bahwa $87,9 \%$ produksi kelapa sawit dipengaruhi oleh variabel input faktor produksi, sedangkan sisanya dipengaruhi oleh faktor lain yang tidak dimasukkan dalam model faktor produksi. Luas lahan memiliki koefisien 0,58 yang berarti apabila luas lahan meningkat $1 \%$ maka akan meningkatkan produksi TBS kelapa sawit sebesar 0,58\%. Pengaruh positif luas lahan terhadap produksi usahatani kelapa sawit sesuai dengan temuan dari penelitian yang telah dilakukan oleh Septianita (2009). Faktor luas lahan sebagai input merupakan variabel yang utama, hal ini dikarenakan makin besar luas lahan maka akan semakin banyak jumlah TM (Tanaman Menghasilkan) kelapa sawit sehingga makin besar produksi TBS (Tandan Buah Segar) yang dihasilkan. Jumlah TM tidak dimasukkan ke dalam faktor produksi dikarenakan jumlah TM/ha-nya relatif tidak memiliki perbedaan jauh antar petani di mana jarak tanam antar pokok relatif menggunakan standar yang sama. Untuk varietas bibit juga tidak dimasukkan ke dalam faktor produksi dikarenakan menggunakan varietas bibit yang sama atau yang cocok dengan lahan gambut, walaupun memiliki sumber yang berbeda dari penamaan jenisnya seperti varietas lame dan varietas topas, tetapi untuk kedua jenis varietas tersebut sama-sama merupakan hasil persilangan antara jenis dura dan pisifera.
Tenaga kerja memiliki koefisien 0,392 yang berarti jika tenaga kerja meningkat $1 \%$ maka akan meningkatkan produksi TBS kelapa sawit sebesar 0,392\%. Dengan nilai signifikansi 1,751 pada tingkat kepercayaan $90 \%$, menunjukkan bahwa jumlah tenaga kerja berpengaruh signifikan terhadap produksi TBS kelapa sawit. Tenaga kerja merupakan salah satu faktor produksi yang penting dalam usahatani kelapa sawit. Dalam usahatani kelapa sawit, tenaga kerja banyak terserap di kegiatan panen dan pengangkutan. Hal ini dikarenakan panen pada usahatani kelapa sawit dilakukan setiap 2 minggu sekali, yang artinya dalam setahun terdapat 24 kali panen. Di lokasi penelitian, rerata curahan tenaga kerja perawatab untuk usahatani kelapa sawit ialah sebesar 4,9 HOK.

Pupuk NPK memiliki koefisien 0,001 yang berarti pupuk NPK jika pupuk NPK meningkat $1 \%$ maka akan meningkatkan produksi TBS kelapa sawit sebesar 0,001\%. Pupuk dolomit memiliki koefisien 0,11 yang berarti apabila pupuk dolomit meningkat 1\% maka akan meningkatkan produksi TBS kelapa sawit sebesar 0,11\%. Pupuk SP36 memiliki koefisien 0,07 yang berarti jika pupuk SP36 meningkat $1 \%$ maka akan meningkatkan produksi TBS kelapa sawit sebesar $0,07 \%$. Pupuk $\mathrm{KCl}$ memiliki koefisien 0,095 yang berarti apabila pupuk $\mathrm{KCl}$ meningkat $1 \%$ maka akan meningkatkan produksi TBS kelapa sawit sebesar 0,095\%. Pupuk urea memiliki koefisien 0,085 yang berarti jika pupuk urea meningkat 1\% maka akan meningkatkan produksi TBS kelapa sawit sebesar $0,085 \%$.

Pada pengaplikasian pupuk yang mempunyai pengaruh positif terhadap produksi TBS hasilnya sejalan terhadap hasil penelitian dari Alwarritzi et al., (2015) dan Septianita (2009). Perbedaannya, penelitian Septianita hanya memasukkan jenis pupuk urea pada input produksi dan pada Alwarritzi input pupuk tidak dibedakan jenisnya.

Pestisida memiliki koefisien -0,052 yang berarti pestisida dan produksi TBS kelapa sawit berkorelasi negatif. Apabila pestisida meningkat $1 \%$ maka akan menurunkan produksi TBS kelapa sawit sebesar 0,052\%. Penggunaan pestisida yang mempunyai 


\section{Muhammad Naufal, Lestari Rahayu Waluyati dan Dwidjono Hadi Darwanto}

Kinerja Usahatani Kelapa Sawit Lahan Gambut di Desa Dayun Kabupaten Siak

pengaruh negatif terhadap produksi TBS hasilnya sejalan terhadap hasil penelitian yang dilakukan Alwarritzi dan Septiananita bahwa pengaruh negatif dari pestisida dapat disebabkan oleh penggunaan yang kurang tepat waktu, jumlah, ataupun jenisnya (Alwarritzi $d k k ., 2015)$ dan (Septiananita, 2009).

Pendidikan petani memiliki koefisien 0,221 yang berarti pendidikan petani dan produksi TBS kelapa sawit berkorelasi positif. Apabila tingkat pendidikan petani bertambah $1 \%$ maka akan meningkatkan produksi TBS kelapa sawit sebesar $0,221 \%$. Umur petani memiliki koefisien 0,238 yang berarti umur petani dan produksi TBS kelapa sawit berkorelasi positif. Apabila umur petani bertambah 1\% maka akan meningkatkan produksi TBS kelapa sawit sebesar $0,238 \%$. Pada pengaruh faktor sosial, terlihat bahwa tingkat pendidikan berpengaruh positif terhadap produksi lahan gambut. Hal ini sejalan dengan penelitian yang dilakukan oleh Juyjaeng (Juyjaeng dkk., 2016).

Penggunaan pestisida yang mempunyai pengaruh negatif terhadap produksi TBS hasilnya sejalan terhadap hasil penelitian yang dilakukan Alwarritzi dan Septianita yang berarti tidak ada faktor jenis tanah yang mempengaruhi pengaruh pestisida terhadap kelapa sawit. Pengaruh negatif dari pestisida mungkin dapat diakibatkan oleh penggunaan yang kurang tepat waktu, jumlah, ataupun jenisnya (Alwarritzi dkk., 2020 dan Septianita, 2009).

Pada pengaruh faktor sosial, dimana tingkat pendidikan berpengaruh positif terhadap produksi lahan gambut sejalan (Juyjaeng dkk., 2016). Begitu juga untuk faktor umur juga mempunyai hasil yang sama-sama tidak signifikan.

\section{Kontribusi Pendapatan}

Pendapatan petani dari usahatani kelapa sawit lahan gambut di Desa Dayun cukup berkontribusi bagi pendapatan total rumah tangga petani sendiri. Berikut ditampilkan sumber pendapatan rumah tangga rata-rata petani kelapa sawit lahan gambut Desa Dayun Kabupaten Siak pada tabel 3 berikut.
Tabel 3

Sumber Pendapatan Rumah Tangga RataRata Petani Kelapa Sawit Lahan Gambut Desa Dayun Kabupaten Siak 2017

\begin{tabular}{llll}
\hline No & $\begin{array}{c}\text { Sumber } \\
\text { Pendapatan }\end{array}$ & $\begin{array}{c}\text { Rerata } \\
\text { Jumlah (Rp) }\end{array}$ & $\begin{array}{c}\text { Kontribusi } \\
(\mathbf{\%})\end{array}$ \\
\hline 1 & $\begin{array}{l}\text { Pendapatan } \\
\text { Sawit }\end{array}$ & 34.163 .618 & 51,78 \\
2 & $\begin{array}{l}\text { Pendapatan } \\
\text { pekarangan } \\
\text { Pendapatan } \\
\text { Ternak/ } \\
\text { perikanan } \\
\text { Pendapatan luar }\end{array}$ & 116.000 & 0,18 \\
\hline & 6.095 .964 & 9,25 \\
\hline $\begin{array}{l}\text { Totahatani } \\
\text { tahun }\end{array}$ & 25.601 .455 & 38,79 \\
\hline
\end{tabular}

Sumber: Analisis data primer, 2018

Pada tabel 3. dapat dilihat bahwa rata-rata jumlah pendapatan kelapa sawit lahan gambut sebesar Rp.34.163.618 dengan kontribusi sebesar $51,78 \%$ terhadap pendapatan total rumah tangga petani. Untuk rata-rata pendapatan yang berasal dari usaha ternak atau perikanan berkontribusi sebesar 9,25\% terhadap total pendapatan rumah tangga petani.

Untuk jumlah petani berdasarkan kontribusi pendapatan sawitnya terhadap pendapatan total rumah tangga dapat dilihat pada tabel 4 berikut:

Tabel 4

Jumlah Responden Petani Kelapa Sawit Menurut Kontribusi Pendapatan Usahatani Kelapa Sawit Desa Dayun Kabupaten Siak 2017

\begin{tabular}{ll}
\hline $\begin{array}{c}\text { Kontribusi Pendapatan Usahatani } \\
\text { Kelapa Sawit Terhadap } \\
\text { Pendapatan rumah tangga (\%) }\end{array}$ & Jumlah Petani \\
\hline$<20$ & 3 \\
$20-40$ & 22 \\
$>40-50$ & 8 \\
$>50-60$ & 7 \\
$>60-80$ & 6 \\
$>80$ & 9 \\
\hline Jumlah & 55 \\
\hline
\end{tabular}

Sumber: Analisis data primer, 2018 
Dari data yang didapat dilakukan uji Z. Dengan tingkat signifikansi $5 \%\left(Z_{, 05}\right.$ tabel: $-1,645)$, nilai $Z$ tabel dibandingkan dengan $\mathrm{Z}$ hitung. Dari hasil perhitungan $\mathrm{Z}$ hitung, didapatkan nilai $Z$ hitung sebesar -1,48 yang berarti nilai $Z$ hitung lebih besar daripada $\mathrm{Z}_{05}$ tabel, sehingga kesimpulan didapat Ho diterima yang artinya setengah petani sawit gambut di Desa Dayun hasil usahatani sawitnya berkontribusi lebih dari 50\% dari total pendapatan rumah tangga.

\section{Tingkat Kemiskinan}

Tingkat kemiskinan penduduk suatu daerah ditentukan dengan melihat nilai garis kemiskinan (GK) penduduk daerah yang akan diteliti. Tingkat kemiskinan petani kelapa sawit lahan gambut di Desa Dayun Kabupaten Siak ditentukan dengan memakai dua pendekatan yaitu pengeluaran konsumsi petani dan pendapatan rumah tangga petani. Kedua hal itu dibandingkan dengan data nilai garis kemiskinan (GK) penduduk daerah penelitian.

GK daerah penelitian termasuk daerah provinsi Riau pada tingkatan pedesaaan, dimana nilai GK yaitu Rp457.368/bulan/ penduduk. Apabila nilai pengeluaran atau pendapatan petani setelah dibagi dengan GK lebih kecil atau sama dengan 1 , maka penduduk dinyatakan miskin. Tingkat kemiskinan Petani kelapa sawit lahan gambut di Desa Dayun dapat dilihat pada tabel 5. berikut:

Tabel 5

Tingkat Kemiskinan Petani Kelapa Sawit Lahan Gambut Desa Dayun Kabupaten Siak 2017

\begin{tabular}{|c|c|c|c|c|c|c|c|}
\hline \multirow{2}{*}{ Kategori } & \multirow{2}{*}{$\begin{array}{l}\text { Sub Kategori } \\
\quad(\text { Level) }\end{array}$} & \multicolumn{3}{|c|}{$\begin{array}{c}\text { Pendekatan "Pengeluaran Konsumsi } \\
\text { rumah tangga Petani" }\end{array}$} & \multicolumn{3}{|c|}{$\begin{array}{c}\text { Pendekatan "Pendapatan rumah } \\
\text { tangga Petani" }\end{array}$} \\
\hline & & $\begin{array}{l}\text { Jumlah } \\
\text { (orang) }\end{array}$ & $\begin{array}{l}\text { Jumlah } \\
\text { (orang) }\end{array}$ & $\begin{array}{c}\text { Persentase } \\
(\%)\end{array}$ & $\begin{array}{l}\text { Jumlah } \\
\text { (orang) }\end{array}$ & $\begin{array}{l}\text { Jumlah } \\
\text { (orang) }\end{array}$ & $\begin{array}{c}\text { Persentase } \\
(\%)\end{array}$ \\
\hline \multirow{2}{*}{ Miskin } & $<=0,75$ & 7 & \multirow{2}{*}{14} & \multirow{2}{*}{25,45} & 1 & \multirow{2}{*}{4} & \multirow{2}{*}{7,27} \\
\hline & $>0,75-1$ & 7 & & & 3 & & \\
\hline \multirow{2}{*}{ Tidak Miskin } & $>1-1,5$ & 19 & \multirow{2}{*}{41} & \multirow{2}{*}{74,55} & 4 & \multirow{2}{*}{51} & \multirow{2}{*}{92,73} \\
\hline & $>1,5$ & 22 & & & 47 & & \\
\hline & & 55 & 55 & 100 & 55 & 55 & 100 \\
\hline
\end{tabular}

Sumber: Analisis data primer, 2018

Dari hasil tabel di atas ditinjau dari pendekatan pengeluaran konsumsi rumah tangga petani, untuk petani yang berkategori miskin di Desa Dayun sebesar 25,45\% dan petani yang tidak miskin sebesar $74,55 \%$. Nilai Z hitung yang didapat adalah 3,634 yang berarti lebih besar dari $-1,645\left(Z_{0,5}\right.$ Tabel). Apabila ditinjau dari tingkat pendapatan rumah tangga petani, untuk petani yang berkatergori miskin di Desa Dayun sebesar 7,27\% dan petani yang tidak miskin sebesar $92,73 \%$. Nilai Z hitung yang didapat adalah 6,34 yang berarti lebih besar dari $-1,645$ ( $Z_{0,5}$ Tabel). Hasil dari tabel di atas menunjukkan hipotesis petani kelapa sawit di Desa Dayun lebih dari 50\% tidak miskin diterima.

Perbedaan angka kemiskinan antara pendekatan tingkat konsumsi dengan pendekatan tingkat pendapatan rumah tangga petani, yaitu memiliki perbedaan sebesar 18,2 $\%$ jumlah rumah tangga petani yang miskin. Hal ini dikarenakan ada rumah tangga petani yang tingkat konsumsinya lebih rendah dibanding tingkat konsumsi minimum yang ditetapkan oleh BPS, padahal pendapatan total rumah tangganya mampu untuk mencukupi kebutuhan konsumsi minimum yang ditetapkan BPS.

\section{SIMPULAN}

Faktor-faktor yang berpengaruh signifikan terhadap produksi usahatani kelapa sawit lahan gambut di Desa Dayun Kabupaten Siak adalah luas lahan, penggunaan tenaga kerja, penggunaan pupuk dolomit, penggunaan pupuk $\mathrm{KCl}$, penggunaan pupuk urea, dan 


\section{Muhammad Naufal, Lestari Rahayu Waluyati dan Dwidjono Hadi Darwanto}

Kinerja Usahatani Kelapa Sawit Lahan Gambut di Desa Dayun Kabupaten Siak

tingkat pendidikan petani. Pendapatan usahatani kelapa sawit lahan gambut di Desa Dayun rata-rata berkontribusi lebih dari 50\% terhadap rerata total pendapatan rumah tangga petani. Setengah dari jumlah petani responden, pendapatan usahatani kelapa sawitnya berkontribusi lebih dari $50 \%$ terhadap pendapatan total rumah tangga. Lebih dari $50 \%$ petani kelapa sawit lahan gambut di Desa Dayun berada pada kategori penduduk tidak miskin.

Produksi kelapa sawit agar dapat meningkat, maka petani sebaiknya menambah penggunaan faktor-faktor produksi seperti: penambahan luas lahan, penggunaan tenaga kerja, pupuk dolomit, pupuk $\mathrm{KCl}$, dan pupuk urea. Tingkat pendidikan juga mempengaruhi peningkatan produksi kelapa sawit, diharapkan petani tentunya melalui keturunan mereka dapat memaksimalkan tingkat pendidikannya agar nantinya dapat menjalankan dan mengembangkan usahatani kelapa sawit yang sudah mereka jalankan dengan hasil produksi yang lebih besar. Perlu dilakukan penelitian tentang alternatifalternatif pengelolaan perkebunan kelapa sawit yang bertujuan mengurangi atau mengatasi faktor-faktor ekonomi yang sering menjadi masalah bagi para petani (small-holder) yang menjalankan usahatani kelapa sawit dalam hal meningkatkan produksi dan pendapatan usahataninya.

\section{DAFTAR PUSTAKA}

Agus, Fahmuddin, Wahyunto, Ai Dariah, Eleonora Runtunuwu, Erni Susanti, dan Wahyu Supriatna. 2012. "Emission Reduction Options for Peatlands in the Kubu Raya and Pontianak Districts, West Kalimantan, Indonesia." Journal of Oil Palm Research 24:1378-87.

Alfayanti dan Zul Efendi. 2013. “Analisis Faktor-Faktor Yang Mempengaruhi Produksi Kelapa Sawit Rakyat Di Kabupaten Mukomuko." Jurnal Agrisep Universitas Bengkulu 13(1):110.
Alwarritzi, Widya, Teruaki Nanseki, dan Yosuke Chomei. 2015. "Analysis of the Factors Influencing the Technical Efficiency among Oil Palm Smallholder Farmers in Indonesia." Procedia Environmental Sciences 28(5):630-38.

Euler, Michael, Vijesh Krishna, Stefan Schwarze, Hermanto Siregar, dan Matin Qaim. 2017. “Oil Palm Adoption, Household Welfare, and Nutrition Among Smallholder Farmers in Indonesia." World Development 93:219-35.

Gupito, Retno Wisti, Irham, dan Lestari Rahayu Waluyati. 2014. “Analisis Faktor-Faktor Yang Mempengaruhi Pendapatan Usahatani Sorgum Di Kabupaten Gunungkidul." Agro Ekonomi 24(1):66-75.

Juyjaeng, Cha-on, Suneeporn Suwanmaneepong, dan Panya Mankeb. 2016. “Economic and Social Factors Affecting Oil Palm Products in the Upper Southern Region: A Case Study of Prachuap Khiri Khan Province, Thailand." International Journal of Agricultural Technology 12(2):1797-1807.

Noormahayu, M. N., A. R. Khalid, dan M. A. Elsadig. 2009. “Financial Assessment of Oil Palm Cultivation on Peatland in Selangor, Malaysia." Mires and Peat 5(2):1-18.

Septianita. 2009. “Faktor-Faktor Yang Mempengaruhi Produksi Kelapa Sawit (Elaeis Quinensis Jack) Dan Kontribusinya Terhadap Pendapatan Keluarga Di Desa Makartitama Kec. Peninjauan Kab. OKU." Jurnal Agronobis 1(2):78-85.

Sunarko. 2009. Budi Daya Dan Pengelolaan Kebun Kelapa Sawit Dan Sistem Kemitraan. Vol. 5. Jakarta: Agromedia Pustaka. 